\title{
Enzyme-based Colorimetric and Potentiometric Biosensor for Detecting Pb (II) Ions in Milk
}

\author{
Hardeep Kaur, Sachin Kumar and Neelam Verma* \\ Biosensor Technology Laboratory; Department of Biotechnology; Punjabi University; Patiala - India
}

\begin{abstract}
The aim of the present work was to study a simple colorimetric and potentiometric biosensor based on urease inhibition by $\mathrm{Pb}$ (II) ions for its estimation in milk samples. Urease immobilized on nylon membrane by hydrosol gel method was used as the biocomponent to demonstrate the metal effect on the enzyme activity using phenol red as the $\mathrm{pH}$ indicator. A lower limit detection of $38.6 \mu \mathrm{m}$ was achieved in the milk and the enzyme membranes were stable for more than two months at $4^{\circ} \mathrm{C}$. In potentiometric approach, response of an ion selective electrode (ISE) to changing ammonium ion concentration as a consequence of urease inhibition by $\mathrm{Pb}$ (II) ions was explored to achieve a detection limit of $9.66 \mu \mathrm{m}$. Lead specificity was attained by means of masking agents 1,10 - phenanthroline and sodium potassium tartarate. Validation of the developed biosensors was carried out with spiked milk samples.
\end{abstract}

Key words: Biosensor, Urease, hydrosol- gel immobilization, lead, milk, masking agent

\section{INTRODUCTION}

The fast urbanization of the society has led to accumulation of many toxic elements, especially heavy metals in the environment. These toxic metals accumulate in the body and result their adverse effects in early or later phase of life. Lead $(\mathrm{Pb})$ is considered as the second most toxic metal and a permissible limit of $10 \mu \mathrm{g} / \mathrm{L}$ in drinking water has been specified by the WHO. The US Center of Disease Control (CDC) has reduced the earlier blood lead intervention from 60 to $10 \mu \mathrm{g}$. According to WHO standards, the permissible limit of lead in drinking water is $10 \mu \mathrm{g} / \mathrm{L}$ and the same for EPA is $15 \mu \mathrm{g} / \mathrm{L}$. At present, there is no maximum residue levels (MRLs) for trace elements in the milk. Codex Alimentarius Commission (2007) has only established a limit of $20 \mu \mathrm{g} / \mathrm{kg}$ lead in the milk.

Lead has been linked to many health hazards, including neurological functions, cardiovascular effects, renal effects, reduced heme biosynthesis, and various gastrointestinal problems. Anemia and reduced intelligence scores has been recently observed in children after exposure to very low levels of $\mathrm{Pb}$ (Roy et al. 2011). Contaminated food consumption has been identified as the major pathway of human exposure for $\mathrm{Pb}$, accounting for $>90 \%$ compared to other ways of exposure such as inhalation and dermal contact (Loufty et al. 2006) and among the foodstuffs, milk is considered to be one of the richest source of lead for humans. The accumulation of lead in the milk is through its uptake by the lactating animals, which graze on soil contaminated with lead by smelting industries, oil leaded paints and gasoline (Wilkinson et al. 2003; Caggiano et al. 2005). Swarup et al. (2005) observed a concentration of $840 \mu \mathrm{g} / \mathrm{L}$ in India and found that the lactating cows with a blood lead level above $200 \mu \mathrm{g} / \mathrm{L}$ had significantly higher milk lead excretion than those below that level. The highest level of lead

*Author for correspondence: verma.neelam2@gmail.com 
$(850 \mu \mathrm{g} / \mathrm{L})$ in the milk has been recorded in lactating cows reared around lead-zinc smelters and steel manufacturing plants (Patra et al. 2008). According to a recent study by Chaudhary and Sharma (2010) in UP, India, children under an age of 5 years had blood lead levels in the range of 30 $-116 \mu \mathrm{g} / \mathrm{L}$.

In view of the above scenario, there is a high need to develop a system that provides low level lead detection in the milk. Although conventional methods such as atomic absorption spectrophotometery (AAS), inductively coupled plasma mass spectrometry (ICP-MS), and differential pulse cathodic stripping voltametry (DPCSV) are able to detect microgram levels of lead, they provide information regarding the concentration only whereas biosensors furnish an insight into the toxicity of the contaminant. Biosensors have gained significance importance as suitable tools for many analytes, including heavy metals. They have the advantage of specificity, low manufacturing cost, higher limits of detection, fast response time, ease of use, portability and ability to furnish continuous real time signals. Several biosensors have been developed for the detection of heavy metal ion in water and food samples but very few have been specified for milk samples, e.g., fiber optic biosensor for Cd detection (Verma et al. 2010). As milk has a complex composition, the biosensor developed for water samples might not always be applicable to milk samples also. A urease based optical biosensor has been reported by Tsai et al. (2003) with a detection limit of $100 \mu \mathrm{M} \mathrm{Pb}$ (II). Haron and Ray (2006) reported a detection limit of $4.83 \mathrm{nM}$ by employing the total reflection technique on urease and actylcholinesterase inhibition. Gani et al. (2010) developed PVCsolgel immobilized urease-based optical biosensor, but did not investigate lead effect. A liquid crystal (LC) based optical biosensor has also been reported by $\mathrm{Hu}$ and Jang (2011). The inadequacy with all these studies was the unaddressed issue of lead specificity and application on complex samples as milk. The present work was carried out to optimize the conditions for milk samples using a microbial urease as the biocomponent and a simple color based detection method for the milk. To make the system more sensitive and lead specific further improvement has been made with the use of Ion Selective Electrode (ISE).

\section{MATERIALS AND METHODS}

All the chemicals used were of analytical grade and procured from Hi-Media, Mumbai and Fluka Chemicals, Germany. The commercially available pasteurized low fat Verka milk samples from Verka Milk plant, Punjab, India were employed in the study.

\section{Microbial cultures}

A urease producing microbe Bacillus badius MTCC 8082 was isolated from the urea-rich soil of National Fertilizers Limited (NFL), Nangal, India. The culture was grown on a medium containing (\%) urea 2.5 , beef extract 1.0 , peptone 1.0 , sodium chloride $0.5, \mathrm{pH} 7.0$ under aerobic conditions at $37^{\circ} \mathrm{C}$ for $24 \mathrm{~h}$.

\section{Enzyme extraction and kinetic characterization}

To extract the enzyme, the methods for both intracellular as well as extracellular extraction were followed. For extracellular extraction, the biomass was separated out from the culture flask by centrifugation at $5000 \mathrm{rpm}$ at $4^{\circ} \mathrm{C}$ for $20 \mathrm{~min}$. The pellet was discarded and the supernatant was mixed with acetone in 1:5 ratio. The mixture was stored in stationary conditions overnight at $4^{\circ} \mathrm{C}$. The pellet was separated by centrifugation as above. The supernatant was discarded. The pellet was mixed with $10 \%$ glycerol, centrifuged again as above and the supernatant was stored at $4^{\circ} \mathrm{C}$ as the crude microbial protein.

The intracellular extraction was carried out by harvesting the biomass in $10 \%$ glycerol and then sonication was done for $5 \mathrm{~min}$ at a specific pulse rate (20 seconds pulse on and 5 second pulse off). The contents obtained were micro-centrifuged and the supernatant obtained was taken as crude protein. The enzyme activity of crude enzyme extract was detected by nesslerization method following Kayastha et al. (1995). The urease produced by the culture catalyzed the hydrolysis of urea according to the reaction:

$\mathrm{NH}_{2} \mathrm{CONH}_{2}+\mathrm{H}_{2} \mathrm{O} \longrightarrow$ Urease $\longrightarrow \mathrm{HCO}_{3}{ }^{-}+2 \mathrm{NH}_{4}{ }^{+}+2 \mathrm{OH}^{-}$

The released carbonic acid and the two molecules of ammonia establish equilibrium with their deprotonated and protonated forms, respectively. The net effect of these reactions is an increase in $\mathrm{pH}$, which is the basis of the present work. The kinetic parameters $\left(\mathrm{K}_{\mathrm{m}}\right.$ and $\mathrm{V}_{\max }$ of the free and immobilized enzyme were studied in the absence 
and presence of $\mathrm{Pb}$ (II) ions to establish the mode of inhibition. For this purpose, different concentrations of substrate $(2.0-10.0 \mathrm{mM})$ were reacted upon by the enzyme according to the defined bioassay and then the enzyme activity values obtained were plotted against the substrate concentration in line-weaverburk plot. Standard deviation was applied to all the results as statistical procedure.

\section{Enzyme assay}

The activity of the crude enzyme was assayed by adding the following reagents in the mentioned proportions: $1.7 \mathrm{~mL}$ urea $(10 \mathrm{mM}), 0.2 \mathrm{~mL}$ of 0.05 $\mathrm{M}$ Tris $-\mathrm{HCl}(\mathrm{pH} \mathrm{7.0)}$ ) and $20 \mu \mathrm{L}$ of the enzyme. The mixture was incubated at $37^{\circ} \mathrm{C}$ for $10 \mathrm{~min}$. Reaction was stopped by adding $0.1 \mathrm{~mL}$ of $1.5 \mathrm{M}$ TCA. Then $2.0 \mathrm{~mL}$ of deionized water and $0.5 \mathrm{~mL}$ of Nessler's reagent was added in the reaction mixture. Contents were again incubated at $37^{\circ} \mathrm{C}$ for $10 \mathrm{~min}$. Absorbance of the test sample versus the blank was read at $405 \mathrm{~nm}$ on double beam UV - Vis spectrophotometer (SYSTRONIC MAKE, MODEL 101).The micromoles of ammonia released were determined from an ammonium chloride standard curve (not included in results).

\section{Immobilization of enzyme}

A stock of hydrosol - gel was prepared from the following reagents: $570 \mu \mathrm{L}$ ethanol, $50 \mu \mathrm{L}$ TEOS, $10 \mu \mathrm{L} \mathrm{NaOH}(5 \mathrm{mM}), 60 \mu \mathrm{L}$ water and kept at $4^{\circ} \mathrm{C}$ for $1 \mathrm{~h}$ (Nepomuscene 2007; Verma et al. 2011). Fifty microliters of crude enzyme (5.3 IU) was mixed with $100 \mu \mathrm{L}$ of sol-gel stock and poured on nylon membrane ( 3 X $3 \mathrm{~cm}$ dimension). The membranes were allowed to dry at room temperature for $1 \mathrm{~h}$ and then used in the reaction. The storage stability of the enzyme membranes was retained by preserving them in glycerol sprinkled tightly capped tubes at $4^{\circ} \mathrm{C}$ and enzyme activity was checked after a regular interval of time period.

\section{Colorimetric Lead detection}

The enzyme membrane prepared by immobilizing $B$. badius urease on nylon membrane was dipped in $9.0 \mathrm{~mL}$ urea $(100 \mathrm{mM})$ solution containing 1.0 $\mathrm{mL}$ lead $(10-20 \mu \mathrm{g} / \mathrm{mL})$. After an incubation period of $10 \mathrm{~min}$, membrane was removed and $100 \mu \mathrm{L}$ of $0.125 \%$ phenol red was added in the solution. Immediately after adding phenol red, absorbance was recorded at $584 \mathrm{nM}$ in the UV Vis spectrophotometer.

\section{Construction of Potentiometric Biosensor}

The potentiometric biosensor was developed by bringing the ISE in close proximity of biocomponent in the form of enzyme immobilized nylon membrane. The ISE containing the membrane at the tip was dipped in $10 \mathrm{~mL}$ Urea $(100 \mathrm{mM})$ solution and the change in potential from zero time till $10 \mathrm{~min}$ was recorded. The same procedure was repeated in the presence of $1.0 \mathrm{~mL}$ lead $(2-200 \mu \mathrm{g} / \mathrm{mL})$ to detect the lowest limit of detection using ISE in water and spiked milk samples. In case of milk samples, $1.0 \mathrm{~mL}$ of spiked milk was added in $9.0 \mathrm{~mL}$ of urea solution and change in the potential was observed. This change in potential was used to calibrate the percentage inhibition, and hence the lower limit of detection.

\section{Effect of masking agents}

In case of potentiometric biosensor, the biosensor was made of lead specific using masking agents such as EDTA, 1, 10 - phenanthroline and sodium potassium tartarate. These masking agents were used to remove the effect of other metal ions on urease and were added in the sample prior to analysis. A control reaction was carried out in the presence of $1 \mathrm{mM}$ EDTA in the sample along with three other reactions, i.e, in the presence of lead only $(20 \mu \mathrm{g} / \mathrm{mL})$, in the presence of all heavy metals, including lead $\left(10 \mu \mathrm{g} / \mathrm{mL}\right.$ of $\mathrm{Hg}^{2+}, \mathrm{Cd}^{2+}$, $\left.\mathrm{Cu}^{2+}, \mathrm{Zn}^{2+}, \mathrm{Fe}^{2+}\right)$, and containing all heavy metals and EDTA. Same kind of reactions were conceded with 1,10 - phenanthroline and sodium potassium tartarate. The optimized conditions were applied directly to the milk and acid extracted milk samples.

\section{Application of constructed Biosensor on milk samples}

A simple acid extraction treatment was given to the milk samples to remove the proteins. The milk was spiked by different lead concentrations and to $10 \mathrm{~mL}$ of milk sample, 2-3 drops of conc. nitric acid were added to coagulate the proteins. The sample was centrifuged to remove the precipitated proteins. The supernatant was analyzed as per the developed method. $\mathrm{NaOH}$ solution was used to retain the original $\mathrm{pH}$ of milk to 6.7-7.0. To all the samples, urea was added to obtain a final urea concentration of $100 \mathrm{mM}$ and enzyme membranes were used to detect the lead concentration colorimetrically and with ISE. 


\section{RESULTS}

\section{Kinetic characterization of free and immobilized enzymes}

Urease was found in the intracellular matrix with an enzyme activity of $13.8 \mathrm{IU}$, no activity was observed in the extracellular protein. Enzyme units were obtained by $\mathrm{NH}_{4} \mathrm{Cl}$ standard curve (Regression Eq: $\mathrm{y}=0.092 \mathrm{x}+0.002, \mathrm{R}^{2}=0.998$ ) The $K_{m}$ and $V_{\max }$ of the free and immobilized enzyme in the absence and presence of lead were obtained as presented in Table 1 . To get the exact inhibition mechanism of the heavy metal, experiment was repeated several times still it was difficult to confirm either it was uncompetitive inhibition or non - competitive. To confirm this, each graph was plotted manually and then standard deviation was applied to all the values, which caused an error bar of $10 \%$ in $\mathrm{K}_{\mathrm{m}}$ value.

Lead was a non- competitive inhibitor of $B$. badius urease, as its presence in the assay mixture showed no effect on $\mathrm{K}_{\mathrm{m}}$ value but decreased the $\mathrm{V}_{\max }$ of the enzyme. Also, decreased $\mathrm{K}_{\mathrm{m}}$ as a consequence of hydrosol- gel immobilization confirmed a higher enzyme - substrate affinity after immobilization. As the studies with lead in the assay reaction showed non- competitive inhibition of urease, a constant concentration of $100 \mathrm{mM}$ urea was selected for biosensor development. The urease containing membranes were stored at $4^{\circ} \mathrm{C}$ and were found to retain up to $85.71 \%$ activity till two months storage, after that enzyme activity decreased constantly.

Table $1-\mathrm{K}_{\mathrm{m}}$ and $\mathrm{V}_{\max }$ values obtained for free and immobilized urease in the absence and presence of lead.

\begin{tabular}{lcccc}
\hline Parameters & $\begin{array}{c}\text { Free enzyme } \\
\text { without } \mathbf{P b}\end{array}$ & $\begin{array}{c}\text { Free Enzyme } \\
\text { with 96.6 mM Pb }\end{array}$ & $\begin{array}{c}\text { Immobilized enzyme } \\
\text { without Pb }\end{array}$ & $\begin{array}{c}\text { Immobilized Enzyme } \\
\text { with 96.6 mM Pb }\end{array}$ \\
\hline $\mathrm{K}_{\mathrm{m}}(\mathrm{mM})$ & $7.69 \pm 0.6$ & $7.69 \pm 0.4$ & $5 \pm 0.7$ & $5 \pm 1.0$ \\
$\mathrm{~V}_{\max }(\mu \mathrm{M} / \mathrm{min})$ & $550 \pm 4.2$ & $380 \pm 3.5$ & $275 \pm 2.8$ & $100 \pm 2.0$ \\
\hline
\end{tabular}

\section{Colorimetric Lead Detection}

Urease containing nylon membranes demonstrated a decline in the color change and absorbance with increase in lead concentration. The lower limit of detection for lead equivalent was $38.6 \mu \mathrm{M}$ in water and milk samples and the enzyme inhibition showed a linear pattern from $48.3-96.6 \mu \mathrm{M}$ in water samples and $38.6-96.6 \mu \mathrm{M}$ in milk samples, respectively (Fig. 1).

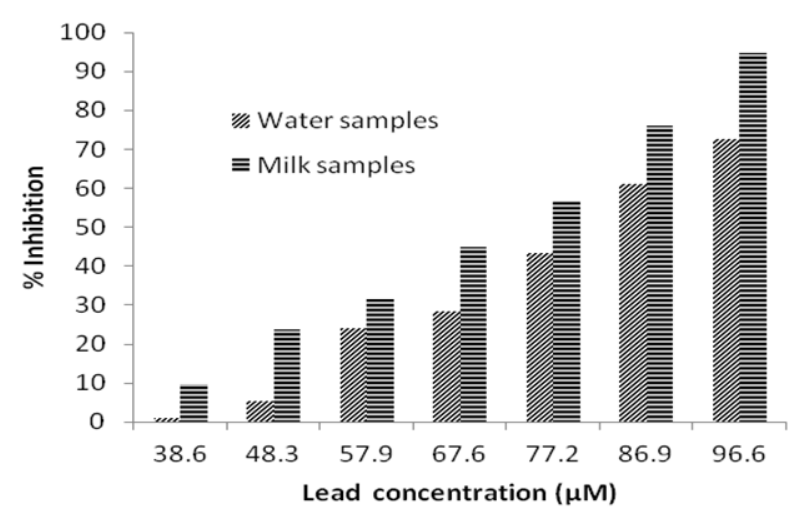

Figure 1 - Lead Inhibition curve in water and milk samples.

The inhibition showed a direct linear relationship with the lead concentration, more the lead added to the sample, more was the inhibition. Being the first report on the inhibition capacity of B. badius, the colorimetric method of metal detection was employed as a basic step to visualize any inhibition. As indicated in the colorimetric and potentiometric lead detection procedure, there was no step to stop the enzyme reaction at any instance for the absorbance or potentiometric measurement. An incubation period of $10 \mathrm{~min}$ was set as stop time to record the final potential with ISE, whereas no such provision could be done during the colorimetric measurement. In case of colorimetric measurement. the incubation time usually deviates from the defined one (due to time consumption in individual sample analysis with spectrophotometer), which leads to increase in the absorbance, and hence reduces the absorbance gap between the successive lead concentrations. This could be the reason of linear relationship between percent inhibition and lead concentration in the colorimetric method. However, with more sensitive ISE and electrochemical measurement as mentioned by Verma et al. (2011), the relationship has always been logarithmic as discussed later in potentiometric biosensor section. The reliability of the method was checked by the recovery studies on the spiked milk samples as shown in Table 2. 
Table 2 - Percentage Recovery in Spiked Milk Samples.

\begin{tabular}{cccl}
\hline $\begin{array}{c}\text { Milk } \\
\text { Samples }\end{array}$ & $\begin{array}{c}\text { Lead Added } \\
(\boldsymbol{\mu M})\end{array}$ & $\begin{array}{c}\text { Lead Found } \\
(\boldsymbol{\mu M})\end{array}$ & $\begin{array}{c}\text { \% } \\
\text { Recovery }\end{array}$ \\
\hline Milk Sample 1 & 48.3 & 57.9 & 119.87 \\
Milk Sample 2 & 67.6 & 77.2 & 114.20 \\
Milk Sample 3 & 86.9 & 96.6 & 111.16 \\
\hline
\end{tabular}

Evidently lead found in the sample was close to the added amount as detected by the developed system. The biocomponent used comprised onetime use disposable membranes, but the use of crude enzyme made it simple and cost effective method for heavy metal detection.

\section{Development of Ion Selective Electrode (ISE) based Potentiometric Biosensor}

A potentiometric biosensor was successfully developed for $\mathrm{Pb}$ (II) ion detection in milk samples. The study was first conducted with free enzyme on water samples and a detection limit of $1.93 \mu \mathrm{M}$ was obtained. A linear range of lead inhibition was obtained from $1.93-4.83 \mu \mathrm{M}$, deduced by the change in potential caused by different lead concentrations. ISE based detection showed a far more sensitive detection than the simple colorimetric method. The observed sensitivity could be attributed to the selective transducer (ion selective electrode) used for the study. Owing to higher sensitivity, the developed method was applied to immobilized enzyme membrane that was tied close to the ISE and same method of detection as free system was employed. Hydrosol - gel method of immobilization was carried out and a detection limit of $9.66 \mu \mathrm{M}$ was obtained in this case. The percentage inhibition at $9.66 \mu \mathrm{M}$ was $8.27 \%$ and a linear range of inhibition from $9.66-966 \mu \mathrm{M}$ was observed (Fig. 2).

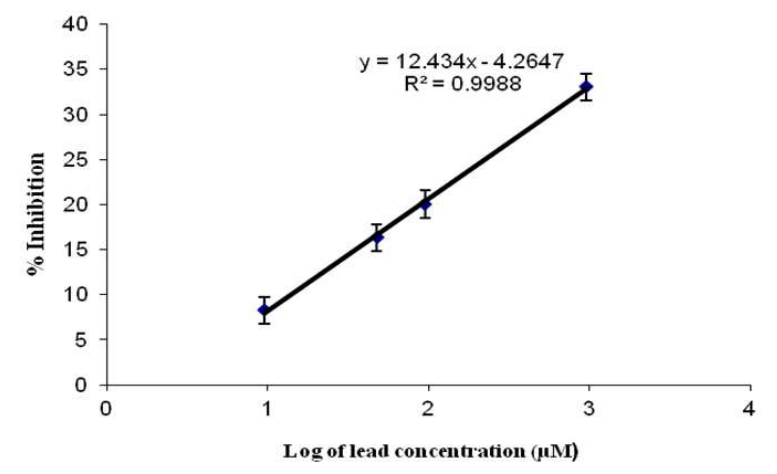

Figure 2 - Lead inhibition studies on ISE.
The relation of percentage inhibition with the lead concentration was logarithmic in this case. It is a well- known fact the influence of heavy metals on enzymes always follows a regular pattern with increase in inhibitor concentration. Heavy metals play an important role as cofactors also for some enzymes, e.g., nickel in case of urease. For this reason, their effect is detectable only after a threshold value over which they are regarded as toxic. The logarithmic pattern of enzyme inhibition is an indication of the same phenomenon. The developed potentiometric biosensor was applied to detect lead in milk samples without any treatment. The detection limit obtained in this case was also $9.66 \mu \mathrm{M}$ with an inhibition of $9.04 \%$ and linear range of inhibition from $9.66-966 \mu \mathrm{M}$ was observed. The potentiometric biosensor was competent to detect lead equivalent contamination up to $9.66 \mu \mathrm{M}$.

\section{Masking Agent Study}

The application of masking agents to invalidate the effect of other heavy metals in the milk was carried out. Results showed that EDTA was able to bring the potential of the milk sample back to the original potential (approximately) in the presence of all heavy metals by masking them as was evident from their potential shift (Table 3).

Table 3 - Urease inhibition study on ISE and EDTA as masking agent for all heavy metals.

\begin{tabular}{lcc}
\hline Sample & $\begin{array}{c}\text { Final } \\
\text { Potential } \\
(\mathbf{m V})\end{array}$ & $\begin{array}{c}\text { Change in } \\
\text { potential } \\
(\Delta \mathbf{m V})\end{array}$ \\
\hline $\begin{array}{l}\text { Control (Milk + 1mM EDTA) } \\
\begin{array}{l}\text { Milk + Lead (97 nanomoles) }+ \\
\text { All other metals (10 } \\
\text { nanomoles ) + EDTA }\end{array}\end{array}$ & $-113.6 \pm 0.6$ & \\
$\begin{array}{l}\text { Milk + Lead (97 nanomoles) } \\
\text { Milk + Lead (97 nanomoles) }+\end{array}$ & $-114.7 \pm 0.3$ & $1.1 \pm 0.2$ \\
All other metals (10 nanomoles) & $-118.5 \pm 0.2$ & $4.9 \pm 0.4$ \\
\hline
\end{tabular}

Apparently $96.6 \mu \mathrm{M}$ of lead decreased the potential from $-113.6 \pm 0.6 \mathrm{mV}$ to $-116.1 \pm 0.4$ $\mathrm{mV}$ that further got decreased to $-118.5 \pm 0.2 \mathrm{mV}$ in the presence of other heavy metal ions, depicting the increased inhibition of urease in their presence. This also confirmed that the inhibition effect of all heavy metals together was more than that of lead alone. The addition of EDTA in the system led to masking of all heavy metals as the potential changed to $-114.7 \pm 0.3 \mathrm{mV}$ that was 
close to control reaction. To mask the effect of all other metals on urease, except lead, 1, 10 phenanthroline and sodium potassium tartarate successfully nullified the effect of all other metals present in the system (Table 4).

Table 4 - Effect of Masking Agent on urease inhibition by metal ions of acid extracted milk.

\begin{tabular}{lcc} 
Sample & $\begin{array}{c}\text { Final } \\
\text { Potential } \\
(\mathbf{m V})\end{array}$ & $\begin{array}{c}\text { Change in } \\
\text { potential } \\
(\Delta \mathbf{m V})\end{array}$ \\
\hline $\begin{array}{l}\text { Control (Milk }+1,10- \\
\begin{array}{l}\text { Phenanthroline and Sodium } \\
\text { potassium tartarate })\end{array}\end{array}$ & $-98.4 \pm 0.4$ & \\
$\begin{array}{l}\text { Milk + Lead }(96.6 \mu \mathrm{M})+\text { All } \\
\text { other metals }(10 \mu \mathrm{M})\end{array}$ & $-116.1 \pm 0.5$ & $17.7 \pm 0.1$ \\
$\begin{array}{l}\text { Milk + Lead }(96.6 \mu \mathrm{M})+\text { All } \\
\text { other metals }(10 \mu \mathrm{M})+1,10-\end{array}$ & $-111.5 \pm 0.7$ & $13.1 \pm 0.3$ \\
$\begin{array}{l}\text { Phenanthroline and Sodium } \\
\text { potassium tartarate }\end{array}$ & & \\
Milk + Lead $(96.6 \mu \mathrm{M})$ & $-111.0 \pm 0.3$ & $11.6 \pm 0.1$
\end{tabular}

The study revealed that the lead and other heavy metal ions caused the inhibition of urease and decreased the potential from $-98.4 \pm 0.4 \mathrm{mV}$ to $116.1 \pm 0.5 \mathrm{mV}$ creating the potential shift of 17.7 $\pm 0.1 \mathrm{mV}$, which decreased to $13.1 \pm 0.3 \mathrm{mV}$ in the presence of 1,10 - phenanthroline and odiusm potassium tartarate. The final potential in the presence of these masking agents was $-111.5 \pm 0.7$ $\mathrm{mV}$ that was close to the one caused by lead alone $(-111.0 \pm 0.3 \mathrm{mV})$. This similar potential suggested that 1,10 - phenanthroline and sodium potassium tartarate were able to mask the effect of all other heavy metals, except lead and showed the same potential drop as caused by lead alone.

\section{DISCUSSION}

The present biosensor was based on easily extractable, cost-effective urease enzyme having lower limit of detection for lead as compared to the expensive enzymes used by other workers. Fennouh et al. (1998) developed an amperometric biosensor with L- lactate dehydrogenase (LDH) and $\mathrm{L}$ - lactate oxidase. The biosensor had a lead detection limit of $0.2 \mu \mathrm{M}$ and the enzyme membranes were stable for more than two months at $4^{\circ} \mathrm{C}$. Kremleva et al. (1999) developed an electrochemical method for determining $\mathrm{Pb}$ (II) ions using an amperometric cysteine desulfhydrolase tissue biosensor; its detection limit was $20 \mathrm{nM}$. The present biosensor had a lower detection limit than the optical sensors developed by Kuswandi (2003) and Tsai et al. (2003) with detection limit of 10 and $100 \mu \mathrm{M}$, respectively. This biosensor could be used for lead detection in the milk samples as also reported by Babkina and Ulakhovich (2004) using ssDNA (detection limit $0.1 \mathrm{nM}$ ). Although the detection limit of the present biosensor was higher than the above one, it had the advantages of low cost and easy pretreatment of the sample. Its detection limit was better than the one developed by Rodriguez et al. (2004), which was based on urease-glutamic dehydrogenase amperometric assay for heavy metal screening in polluted samples. The biosensor detected $\mathrm{Pb}$ (II) level more than $2.4 \times 10^{-1} \mathrm{mM}$. Ogonczyk et al. (2005) developed a screen printed disposable urease based biosensor for the detection of heavy metals and reported a detection limit of 1 $\mathrm{mM}$ of lead in $20 \mathrm{~min}$ response time. Haron and Ray (2006) reported an optical biosensor with very low detection limit of $4.83 \mathrm{nM}$, but had application in drinking water samples only. The present biosensor was economical than that reported by Bagal - Kestwal et al. (2008). They obtained a detection limit of $30 \mathrm{nM}$ in 10 min contact time by studying the inhibition of invertase and glucose oxidase on electrochemical transducer. Several DNAzyme based sensors have been reported with detection limit ranging from $10 \mathrm{nM}$ to $500 \mathrm{nM}$ (Liu and Lu 2000; Wei et al. 2008; Wang and Irudayaraj 2011).

To conclude, in this work, an enzyme inhibition based simple colorimetric biosensor was constructed for the estimation of lead in milk samples after a treatment of milk samples. Urease enzyme immobilized on nylon membrane through hydrosol - gel procedure was employed as the biocomponent. The developed potentiometric biosensor detected lead specifically in the milk without any pretreatment. Lead specificity was attained with the use of masking agents. This biosensor could be used for the estimation of lead in other matrices also such as industrial effluents and alloys.

\section{ACKNOWLEDGEMENT}

The authors are thankful to ICAR (NAIP), New Delhi, India for the research grant C4/C10125/2008 supporting this work. 


\section{REFERENCES}

Babkina SS, Ulakhovich NA. Amperometric biosensor based on denatured DNA for the study of heavymetals complexing with DNA and their determination in biological, water and food samples. Bioelectrochem. 2004; 63: 261-265.

Bagal-Kestwal D, Karve MS, Kakade B, Pillai VK. Invertase inhibition based electrochemical sensor for the detection of heavy metal ion in aqueous system: Application of ultra-microelectrode to enhance sucrose biosensor's sensitivity. Biosens Bioelectron. 2008; 24: 657-664.

Caggiano R, Sabia SD, Emilio M, Macchialo M, Anastasio A, Ragosta M et al. Metal levels in fodder, milk, dairy products and tissues samples in ovine farms of southern Italy. Enivron Res. 2005; 99: 4857.

Chaudhary V, Sharma MK. Blood lead level in the children of western Uttar Pradesh, India. Toxic Env Chem. 2010; 1029-1486.

Fennouh S, Casimiri V, Geloso-Major A, Burstein C. Kinetic study of heavy metal salt effects on the activity of L- lactate dehydrogenase in solution or immobilized on an oxygen electrode. Biosens Bioelectron. 1998; 13: 903-909.

Gani AA, Ashari MR, Kuswandi B. An optical fiber biosensor for heavy metal ions based on o modified single solgel film of urease and chlorophenol red in flow system. Sensor Lett. 2010; 8(2): 320-327.

Haron S, Ray AK. Optical biodetection of cadmium and lead ions in water. Med Eng Phy. 2006; 28: 978-981.

Hu QZ, Jang CH. Liquid crystal based sensors for the detection of heavy metals using surface immobilized urease. Colloid Surface B. 2011; 88(2): 622-626.

Kayastha AM, Das N, Malhotra OP. Urease from the seeds of pigeonpea (Cajanus cajan L.). In: Svasti J, editor. Biopolymers and Bioproducts: Structure, Function and Application. Bangkok: Dokya Pub; 1995. p. 382-386.

Kremleva NV, Medyantseva EP, Budnikov GK, Bormotova YI. Amperometric biosensor for monitoring lead and cadmium. J Anal Chem. 1999; 54(2): 151-154.

Kuswandi B. Simple optical fiber biosensor based on immobilized enzyme for monitoring of trace heavy metal ions. Anal Bioanal Chem. 2003; 376: 11041110.

Liu J, Lu Y. A highly sensitive and selective catalytic DNA Biosensor for Lead ions. J Am Chem Soc. 2000; 122: 10466-10467.

Loufty N, Fuerhacker M, Tundo P, Raccanelli S, El Dien AG, Ahmed MT. Dietary intake of dioxins and dioxins like PCBs, due to the consumption of dairy products, fish/ seafood and meat from Ismailia city. Sci Total Env. 2006; 370: 1-8.
Nepomuscene NJ, Daniel D, Krastanov A. Biosensor to detect chromium in waste water. Biotechnol Biotec Eq. 2007; 21: 377-81.

Ogonczyk D, Tymecki L, Wyzkiewicz T, Koncki R, Glab S. Screen printed disposable urease based biosensors for inhibitive detection of heavy-metal ions. Sens and Actu. B. 2005; 106: 450-454.

Patra RC, Swarup D, Kumar P, Nandi D, Naresh R, Ali SL. Milk trace elements in lactating cows environmentally exposed to higher level of lead and cadmium around different industrial units. Sci Total Env. 2008; 404: 36-43.

Rodriguez BB, Bolbot JA, Tothill EE. Development of urease and glutamic dehydrogenase amperometric assay for heavy metals screening in polluted samples. Biosens Bioelectron. 2004: 19: 1157-1167.

Roy A, Hu H, Bellinger DC, Mukherjee B, Modali R, Nasaruddin K. et al. Hemoglobin, lead exposure, and intelligence quotient: effect modification by the DRD2 Taq IA polymorphism. Environ Health Perspect. 2011; 119(1): 144-9.

Swarup D, Patra RC, Naresh R, Kumar P, Shekhar P. Blood lead levels in lactating cows reared around polluted localities; transfer of lead into milk. Sci Total Env. 2005; 349: 67-71.

Tsai HC, Doong RA, Chiang MS, Chen, KI. Sol-gel derived urease based optical biosensor for the rapid determination of heavy metals. Laxal Acta. 2003; 481: 75-84.

Verma N, Kaur H, Kumar S. Whole cell based electrochemical biosensor for monitoring lead ions in milk. Biotechnol. 2011a; 10(3): 256-266.

Verma N, Kumar S, Kaur H. Fiber Optic biosensor for detection of cadmium in milk. $J$ Biosens Bioelectron. 2010; 1: 102.

Verma N, Kumar S, Kaur H. Whole cell based disposable biosensor for Cadmium detection in milk. Adv Appl Sci Res. 2011b; 2(6): 354-363

Wang Y, Irudayaraj J. A SERS DNAzyme biosensor for lead ion detection. Chem Commun. 2011; 47: 4394-4396.

Wei H, Li B, Li J, Dong S, Wang E. DNAzyme based colorimetric sensing of lead using unmodified gold nanoparticle probes. Nanotechnology. 2008: 19: 95501-95505.

Wilkinson JM, Hill J, Phillips CJC. The accumulation of potentially toxic metals by grazing ruminants. $P$ Nutr Soc. 2003; 62: 267-277. 